\title{
A Randomized, Masked Study of Triiodothyronine Plus Thyroxine Administration in Preterm Infants Less Than 28 Weeks of Gestational Age: Hormonal and Clinical Effects
}

\author{
PAOLO G. VALERIO, ALEID G. VAN WASSENAER, JAN J.M. DE VIJLDER, AND JOKE H. KOK \\ Department of Neonatology [P.G.V., A.G.v.W., J.H.K.] and Laboratory of Pediatric Endocrinology \\ [J.J.M.d.V.], Academic Medical Center, Emma Children's Hospital, 1105 AZ Amsterdam, The Netherlands
}

\begin{tabular}{|c|c|}
\hline \multicolumn{2}{|c|}{ ABSTRACT } \\
\hline $\begin{array}{l}\text { A randomized, placebo-controlled, masked study was con- } \\
\text { ducted of the responses of thyroid parameters, cortisol, and the } \\
\text { cardiovascular system to a single dose of triiodothyronine }\left(\mathrm{T}_{3}\right) \\
24 \mathrm{~h} \text { after birth, followed by a daily dose of thyroxine }\left(\mathrm{T}_{4}\right) \text { during } \\
6 \text { wk to infants }<28 \text { wk gestational age. Thirty-one infants were } \\
\text { assigned to three groups: } 1) \text { group } \mathrm{A} \text { : } \mathrm{T}_{3} 24 \mathrm{~h} \text { after birth plus } \\
\left.\text { daily } \mathrm{T}_{4} \text { during } 6 \text { wk; } 2\right) \text { group } \mathrm{B} \text { : placebo } \mathrm{T}_{3} \text { and } \mathrm{T}_{4} \text { during } 6 \text { wk; } \\
\text { and } 3 \text { ) group C: placebo } \mathrm{T}_{3} \text { and placebo } \mathrm{T}_{4} . \mathrm{T}_{4} \text {, free } \mathrm{T}_{4}, \mathrm{~T}_{3} \text {, free } \\
\mathrm{T}_{3} \text {, reverse } \mathrm{T}_{3} \text {, thyroid-stimulating hormone, and cortisol were } \\
\text { measured in cord blood and on days } 1,3,7,14,21,42 \text {, and } 56 \text {. } \\
\text { Data on pulse rate, blood pressure, and cumulative dose of } \\
\text { inotropic agents were collected. } \mathrm{T}_{3}(0.5 \mu \mathrm{g} / \mathrm{kg}) \text { resulted in a } \\
\text { plasma increase until day } 3 \text {. Thereafter, plasma } \mathrm{T}_{3} \text { levels were } \\
\text { comparable between the groups. } \mathrm{T}_{4} \text {, free } \mathrm{T}_{4} \text {, and reverse } \mathrm{T}_{3} \text { were } \\
\text { increased in groups A and } \mathrm{B} \text { during the period of } \mathrm{T}_{4} \text { adminis- } \\
\text { tration. Thyroid-stimulating hormone suppression was of shorter } \\
\text { duration in group A. } \mathrm{T}_{3} \text { and } \mathrm{T}_{4} \text { administration did not have any }\end{array}$ & $\begin{array}{l}\text { effect on cortisol levels. We did not find any effects of } \mathrm{T}_{3} \text { or of } \\
\mathrm{T}_{4} \text { administration on the cardiovascular system. A single injec- } \\
\text { tion of } \mathrm{T}_{3}(0.5 \mu \mathrm{g} / \mathrm{kg} \text { ) given } 22-26 \mathrm{~h} \text { after birth only leads to a } \\
\text { 2-d increase of } \mathrm{T}_{3} \text { levels and does not have effects on the } \\
\text { cardiovascular system. This study does not support the use of } \mathrm{T}_{3} \\
\text { according to our regimen in preterm infants. (Pediatr Res } \mathbf{5 5} \text { : } \\
\mathbf{2 4 8 - 2 5 3 , 2 0 0 4 )} \\
\mathbf{T}_{3} \text {, triiodothyronine Abbreviations } \\
\mathbf{T}_{4} \text {, thyroxine } \\
\text { TSH, thyroid-stimulating hormone }_{\text {GA, gestational age }} \\
\mathbf{G T}_{\mathbf{3}} \text {, reverse } \mathrm{T}_{3} \\
\text { FT }_{\mathbf{4}} \text {, free } \mathrm{T}_{4} \\
\text { FT }_{3} \text {, free } \mathrm{T}_{3}\end{array}$ \\
\hline
\end{tabular}

Thyroid hormones play an important role in normal growth and development of the CNS $(1,2)$. In term infants, thyroxine $\left(\mathrm{T}_{4}\right)$ and triiodothyronine $\left(\mathrm{T}_{3}\right)$ increases shortly after birth. In premature infants, transient hypothyroxinemia after birth is a common finding (3-7). This hypothyroxinemia is characterized by low levels of $\mathrm{T}_{4}$ and $\mathrm{T}_{3}$, which do not cause elevations in thyroid-stimulating hormone (TSH) above $20 \mathrm{mU} / \mathrm{L}$. The degree of hypothyroxinemia is related to gestational age (GA) and the severity of neonatal disease. Low $T_{3}$ and $T_{4}$ levels in premature infants have been found to be associated with poor neurologic and developmental outcome (8-11).

Transient hypothyroxinemia is a multicausal phenomenon in which immaturity of thyroid hormone metabolism with high activity of deiodinase type 3 together with factors such as

Received February 17, 2003; accepted July 4, 2003.

Correspondence: Aleid G. van Wassenaer M.D., Ph.D., Department of Neonatology, Emma Children's Hospital AMC, Meibergdreef 9, 1105 AZ Amsterdam, The Netherlands; e-mail: a.vanwassenaer@amc.uva.nl

DOI: 10.1203/01.PDR.0000104153.72572.F5 immaturity of the hypothalamo-pituitary-thyroid axis and the sudden interruption of the maternal contribution to fetal thyroid hormone pools are involved. Thyroid hormone supplementation in preterm infants has been the subject of several clinical studies with clinical and neurodevelopmental parameters as primary outcome (12-14). To date, no clear effect of supplemental $\mathrm{T}_{4}$ treatment on neurodevelopmental outcome has been demonstrated. In an earlier study, however, we observed that a subgroup of $\mathrm{T}_{4}$-treated infants of $<29 \mathrm{wk}$ GA tended to have a better developmental outcome than infants of similar GA in the placebo group $(13,15)$.

$\mathrm{T}_{4}$ administration to preterm infants of $<30 \mathrm{wk}$ GA did not result in increased plasma $\mathrm{T}_{3}$ levels; in fact, it resulted in decreased plasma $T_{3}$ levels and increased plasma reverse $T_{3}\left(\mathrm{rT}_{3}\right)$ levels (16). It was suggested that this $\mathrm{T}_{3}$ decrease was caused by lower endogenous thyroidal $\mathrm{T}_{3}$ production as a result of TSH suppression and that, because of low thyroidal and hepatic type 1 deiodinase activity and high deiodinase type 3 activity, an increase in plasma $T_{4}$ did not result in an increase in plasma $T_{3}$. 
Although the $\mathrm{T}_{3}$ decrease after $\mathrm{T}_{4}$ administration did not result in worse clinical outcome, a $\mathrm{T}_{3}$ increase shortly after birth could very well improve clinical outcome. We hypothesized that a single dose of $T_{3}$ is able to switch on deiodinating enzymes and thus simulate the rapid postnatal increase of $\mathrm{T}_{3}$ levels as is especially seen in more mature infants. This increase in $T_{3}$ levels is thought to be necessary for metabolic adaptation after birth.

In an earlier study using historical controls, we described that a single dose of $\mathrm{T}_{3} 12 \mathrm{~h}$ after birth resulted in a sustained increase of plasma $T_{3}$ both if given as a single treatment and in combination with 6 wk of $T_{4}$ supplementation. Because this study was done with a historical control group, these results need to be reproduced in a randomized trial (17).

The aim of the current study was to investigate the hormonal effects of three supplementation schemes $\left(T_{4}\right.$ plus $T_{3}, T_{4}$ plus placebo, and placebo) in a randomized, masked way in infants $<28$ wk GA. In addition, we measured plasma cortisol levels concurrently with thyroid hormone levels. This was done because, to our knowledge, until now, there are no reports on the influence of transient hypothyroxinemia in preterm infants on adrenal cortex function, whereas glucocorticoid hormones and thyroid hormones are known to be functionally interrelated with respect both to maturational effects and to influencing each other's regulatory pathways $(18,19)$.

In several pediatric studies, it has been suggested that $T_{3}$ administration improves myocardial function, especially after cardiac surgery (20-22). In an earlier study, we found higher heart rates in children who received only $\mathrm{T}_{4}(23)$. For studying the effects of $T_{3}$ plus $T_{4}$ administration on the cardiovascular system, intra-arterial blood pressure, heart rates, and cumulative doses of inotropic agents were measured in all infants included in the current study.

\section{METHODS}

Eligibility and randomization. This study was approved by the Committee of Medical Ethics of the Academic Medical Center in Amsterdam (The Netherlands) and by the National Committee on Human Research. Infants who were admitted to our neonatal intensive care unit and were born between September 2000 and September 2001 with a GA $<28$ wk were eligible for the study. Infants were excluded when they had a severe congenital anomaly or when there was maternal endocrine disease. When informed consent had been obtained from at least one of the parents within $24 \mathrm{~h}$ after birth, the infant was included in the study.

After inclusion, the infants were randomized to receive $T_{3}$ plus $\mathrm{T}_{4}$ (group $\mathrm{A}$ ), placebo- $\mathrm{T}_{3}$ plus $\mathrm{T}_{4}$ (group $\mathrm{B}$ ), or placebo- $\mathrm{T}_{3}$ plus placebo- $\mathrm{T}_{4}$ (group C). Randomization took place with the use of a computerized randomization program in blocks of five. Randomization was stratified according to GA ( $27 \mathrm{wk}$ and $<27$ wk). All investigators, medical staff, and parents remained unaware of the infants' study-group assignment throughout the study.

Intervention. For each infant who entered the study, a numbered set of 1 ampoule containing $\mathrm{T}_{3}$ or placebo and 50 ampoules containing $T_{4}$ or placebo was prepared. $T_{3}$ was given in a single i.v. dose of $0.5 \mu \mathrm{g} / \mathrm{kg} 22-26 \mathrm{~h}$ after birth. $\mathrm{T}_{4}$ was given in a daily i.v. dose of $8 \mu \mathrm{g} / \mathrm{kg}$ during $42 \mathrm{~d}$ starting immediately after the single dose of $T_{3}$. As in previous studies of our group $(13,17), \mathrm{T}_{4}$ was given by enteral route when all feeding was given enterally.

Thyroid hormone and cortisol determinations. The primary outcome was thyroid function measured as plasma levels of $\mathrm{T}_{4}$, free $\mathrm{T}_{4}\left(\mathrm{FT}_{4}\right), \mathrm{T}_{3}$, free $\mathrm{T}_{3}\left(\mathrm{FT}_{3}\right), \mathrm{rT}_{3}, \mathrm{TSH}$, and plasma cortisol levels. Blood samples $(1 \mathrm{~mL})$ were taken from cord blood $24 \mathrm{~h}$ after birth (just before $\mathrm{T}_{3}$ administration) and again on days 3 , $7,14,21,42$, and 56. Furthermore, $0.3-\mathrm{mL}$ blood samples were taken 30,120 , and 360 min after $\mathrm{T}_{3}$ administration for determination of $\mathrm{T}_{3}$ levels.

$\mathrm{T}_{4}, \mathrm{~T}_{3}$, and $\mathrm{rT}_{3}$ were measured by in-house RIA methods. $\mathrm{FT}_{3}, \mathrm{FT}_{4}$, and TSH were measured by time-resolved fluoroimmunoassay (Delfia $\mathrm{FT}_{4}$, respectively, Delfia $\mathrm{FT}_{3}$ and Delfia hTSH Ultra; Wallac Oy, Turku, Finland). Cortisol was measured by luminescence enzyme immunoassay (Immulite; Diagnostic Products Corporation, Los Angeles, CA, U.S.A.)

Detection limits were as follows: $\mathrm{T}_{4}, 5 \mathrm{nmol} / \mathrm{L} ; \mathrm{T}_{3}, 0.3$ $\mathrm{nmol} / \mathrm{L} ; \mathrm{rT}_{3}, 0.03 \mathrm{nmol} / \mathrm{L} ; \mathrm{FT}_{3}, 1 \mathrm{pmol} / \mathrm{L} ; \mathrm{FT}_{4}, 2 \mathrm{pmol} / \mathrm{L} ; \mathrm{TSH}$, $0.01 \mathrm{mU} / \mathrm{L}$; and cortisol, $30 \mathrm{nmol} / \mathrm{L}$. Intra-assay variations were as follows: $\mathrm{T}_{4}, 2-4 \% ; \mathrm{T}_{3}, 3-4 \% ; \mathrm{rT}_{3}, 4-5 \% ; \mathrm{FT}_{3}, \pm 6 \%$; $\mathrm{FT}_{4}, 4-6 \%$; $\mathrm{TSH}, 1-2 \%$; cortisol, 3.6-6.4\%. Interassay variations were as follows: $\mathrm{T}_{4}, 3-6 \% ; \mathrm{T}_{3}, 7-8 \% ; \mathrm{rT}_{3}, 5-9 \% ; \mathrm{FT}_{3}$, $\pm 9 \%$; $\mathrm{FT}_{4}, 5-8 \%$; TSH, 3-4\%; cortisol, 4.7-9.0\%.

Cardiovascular measurements. Secondary outcomes were daily mean heart rate, daily mean intra-arterial blood pressure during the first week of life, and cumulative dose of inotropic agents. These data all were collected prospectively. Daily mean heart rate and intra-arterial blood pressure were calculated as the mean of four values at predefined time points $(0400,1000$, 1600 , and $2200 \mathrm{~h}$ ). Cumulative doses of inotropic agents were calculated over the total study period and each of the first $4 \mathrm{~d}$ after $\mathrm{T}_{3}$ administration separately.

Statistical analysis. Data analysis was done using SPSS version 10.0.7 (SPSS Inc., Chicago, IL, U.S.A.). The one-way ANOVA with Bonferroni post hoc analysis was used to compare continuous variables in the three study groups. For analysis of categorical data, the $\chi^{2}$-test $(3 \times 2$ tables $)$ was used. Statistical significance was set at $p=0.05$.

\section{RESULTS}

Patients. Between September 1, 2000, and September 1, 2001, 42 infants were eligible for the study. Five infants died before consent could be asked. For three infants, consent was not given. Two infants were excluded because of severe congenital malformations and one because of thyroid illness of the mother.

Population characteristics of the remaining 31 infants enrolled in the study are shown in Table 1. In group A, mean birth weight was lowest and percentage of small-for-gestational-age infants was highest (NS). Clinical characteristics of the infants who were enrolled in the study are shown in Table 2. Infants in group A seemed to be sicker because they had a significantly higher incidence of intraventricular hemorrhage grades 3 and 4. They also needed higher cumulative doses of inotropic 
Table 1. Baseline characteristics of the infants in the three study groups

\begin{tabular}{|c|c|c|c|}
\hline & $\begin{array}{c}\text { Group } \mathrm{A}\left(\mathrm{T}_{3}^{+} \mathrm{T}_{4}^{+}\right) \\
(n=11)\end{array}$ & $\begin{array}{c}\text { Group B }\left(\mathrm{T}_{3}^{-} \mathrm{T}_{4}{ }^{+}\right) \\
(n=10)\end{array}$ & $\begin{array}{c}\text { Group } \mathrm{C}\left(\mathrm{T}_{3}{ }^{-} \mathrm{T}_{4}{ }^{-}\right) \\
(n=10)\end{array}$ \\
\hline Birth weight (g) & $889 \pm 60$ & $982 \pm 67$ & $1067 \pm 35$ \\
\hline Gestational age (d) & $189 \pm 1.25$ & $190 \pm 1.36$ & $188 \pm 1.07$ \\
\hline Male/female & $8 / 3$ & $5 / 5$ & $7 / 3$ \\
\hline Premature rupture of membranes* & $3(27)$ & $1(10)$ & $3(30)$ \\
\hline Antenatal steroids* & $9(82)$ & $10(100)$ & $8(80)$ \\
\hline Interquartile range & $3-10$ & $4-9$ & $4-9$ \\
\hline Intubation at birth* & $9(82)$ & $8(80)$ & $8(80)$ \\
\hline
\end{tabular}

Plus-minus values are means \pm SEM. Other values are number of infants. There were no statistically significant differences among the three groups.

* Number of infants and (percentage of total study group).

Table 2. Clinical characteristics of the infants in the three study groups

\begin{tabular}{|c|c|c|c|}
\hline & $\begin{array}{c}\text { Group A }\left(\mathrm{T}_{3}{ }^{+} \mathrm{T}_{4}{ }^{+}\right) \\
(n=11)\end{array}$ & $\begin{array}{c}\text { Group } \mathrm{B}\left(\mathrm{T}_{3}^{-} \mathrm{T}_{4}^{+}\right) \\
(n=10)\end{array}$ & $\begin{array}{c}\text { Group C }\left(\mathrm{T}_{3}{ }^{-} \mathrm{T}_{4}{ }^{-}\right) \\
(n=10)\end{array}$ \\
\hline Surfactant therapy* & $7(64)$ & $7(70)$ & $6(60)$ \\
\hline Time on mechanical ventilation $(\mathrm{d}) \dagger$ & $11.4 \pm 2.9$ & $10.9 \pm 1.1$ & $11.6 \pm 4.9$ \\
\hline Oxygen dependency at $28 \mathrm{~d}$ postnatal age $* \dagger$ & $4(57)$ & $6(86)$ & $7(88)$ \\
\hline Dexamethasone therapy*§ & $1(9)$ & $2(20)$ & $1(10)$ \\
\hline Cumulative dose of inotropic agents $(\mathrm{mg} / \mathrm{kg})$ & $110.5 \pm 63.0$ & $45.9 \pm 22.4$ & $30.6 \pm 16.2$ \\
\hline Septicemia*t & $6(55)$ & $1(10)$ & $4(40)$ \\
\hline Death* & $4(36)$ & $3(30)$ & $2(20)$ \\
\hline
\end{tabular}

Plus-minus values are means \pm SEM.

* Number of infants and (percentage of total study group).

$\dagger$ Analysis of surviving infants only.

$\$$ Number of children with at least one period of septicemia, confirmed by positive bacterial culture.

$\S$ Dexamethasone therapy was indicated when an infant could not be weaned from the ventilator after 2 wk of mechanical ventilation. Dexamethasone was given in a course of $3 \mathrm{wk}$ in a daily dose of $0.5 \mathrm{mg} / \mathrm{kg}$ tapered to $0.1 \mathrm{mg} / \mathrm{kg}$.

$\| p=0.047$; there were no statistically significant differences in the other clinical characteristics among the three groups.

agents and had more septicemia than infants in groups B and C, but these differences were not significant. All 31 children included received the intervention as described above until day 42 or, if earlier, until death.

Hormonal outcome. Figure 1 shows the time course of the mean plasma concentrations of $\mathrm{T}_{3}, \mathrm{FT}_{3}, \mathrm{~T}_{4}, \mathrm{FT}_{4}, \mathrm{TSH}, \mathrm{rT}_{3}$, and cortisol. Mean $\mathrm{T}_{3}$ levels in group $\mathrm{C}$ (placebo group) remained low at approximately $0.7 \mathrm{nmol} / \mathrm{L}$ until approximately day 7 ; thereafter, mean $\mathrm{T}_{3}$ levels rose gradually to approximately 3.0 $\mathrm{nmol} / \mathrm{L}$ on day 56 .

In group $\mathrm{B}, \mathrm{T}_{3}$ levels were similar to the placebo group until approximately day 3 . From day 7 onward, however, $\mathrm{T}_{3}$ levels remained lower compared with the placebo group without reaching statistical significance.

In group $\mathrm{A}$, after $\mathrm{T}_{3}$ administration, there was a $200 \%$ increase compared with groups $\mathrm{B}$ and $\mathrm{C}$ with a maximum at 30 min after injection. At $5.5 \mathrm{~h}$ after this maximum, $\mathrm{T}_{3}$ levels were already decreased by $30 \%$. On day $3, \mathrm{~T}_{3}$ levels were comparable to levels in group $\mathrm{B}$. In group $\mathrm{A}, \mathrm{T}_{3}$ concentrations were somewhat higher on day 21 and day 42 compared with group $\mathrm{B}$ but not significantly.

Mean $\mathrm{FT}_{3}$ levels remained comparable among the three groups until day 21 . On day 42 , the mean $\mathrm{FT}_{3}$ level in group $\mathrm{B}$ was lower but not significantly lower than the mean $\mathrm{FT}_{3}$ levels in groups $\mathrm{A}$ and $\mathrm{C}$. On day 56, mean $\mathrm{FT}_{3}$ levels were comparable among the groups.

Mean $\mathrm{FT}_{4}$ levels in group $\mathrm{C}$ remained between 10.3 and 12.9 $\mathrm{pmol} / \mathrm{L}$ during the first $14 \mathrm{~d}$ and increased slowly to approximately $15 \mathrm{pmol} / \mathrm{L}$ on day 56 . In groups $\mathrm{A}$ and $\mathrm{B}$, mean $\mathrm{FT}_{4}$ levels showed a clear elevation in the first $21 \mathrm{~d}$ of $\mathrm{T}_{4}$ administration. Thereafter, the differences with the placebo group gradually disappeared. Two weeks after discontinuation of $\mathrm{T}_{4}$ administration, $\mathrm{FT}_{4}$ levels were similar in the three groups. $\mathrm{T}_{3}$ administration did not have any effect on mean $\mathrm{FT}_{4}$ levels.

Mean $\mathrm{T}_{4}$ levels showed the same pattern as the mean $\mathrm{FT}_{4}$ levels, but significance was not reached. Mean TSH levels in all groups initially showed the highest values (approximately 7 $\mathrm{mU} / \mathrm{L}$ ) in cord blood. In group C, the mean TSH levels dropped to approximately $3 \mathrm{mU} / \mathrm{L}$ at $24 \mathrm{~h}$ after birth and showed an increase at approximately day 14 . Thereafter, mean TSH levels gradually decreased again to approximately $3 \mathrm{mU} / \mathrm{L}$.

In groups A and B, mean TSH levels fell deeper to $<1 \mathrm{mU} / \mathrm{L}$ on day 3. Mean TSH levels were equally suppressed in groups $\mathrm{A}$ and $\mathrm{B}$ during the first $21 \mathrm{~d}$. After day 21, mean TSH levels in group A seemed to be less suppressed than in group B, and on day 42, mean TSH levels were decreased only in the children who received only $\mathrm{T}_{4}$. After cessation of $\mathrm{T}_{4}$ administration, TSH levels were comparable in all three groups. 
A

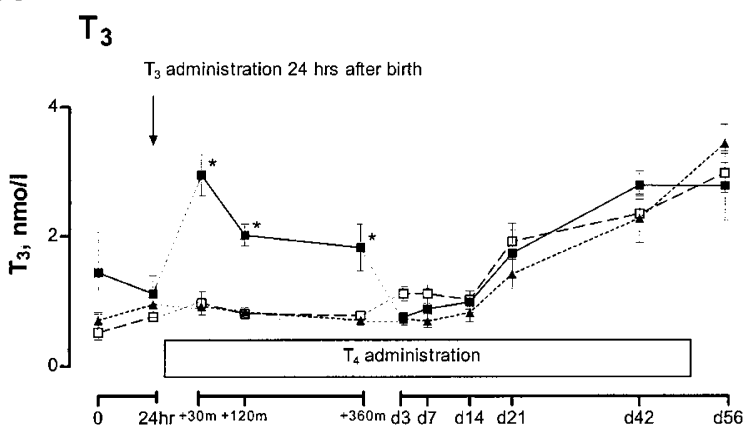

C

$\mathrm{FT}_{4}$

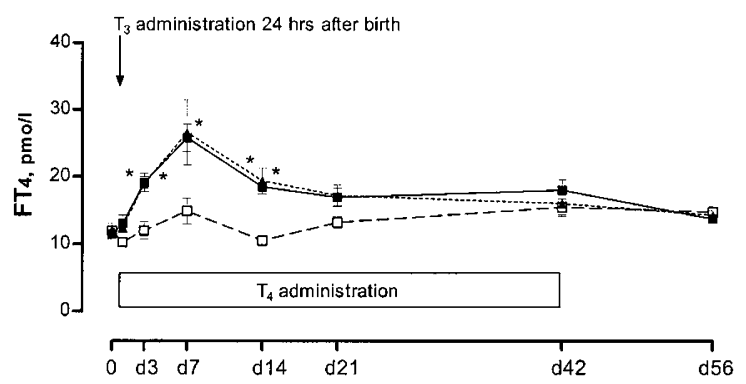

E

TSH

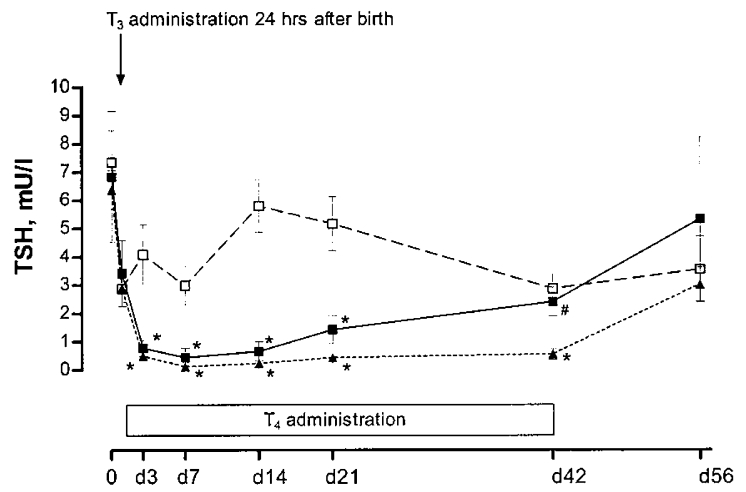

B

$\mathrm{FT}_{3}$

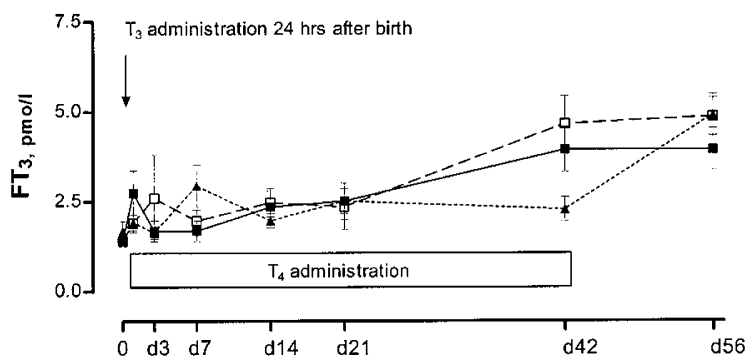

D

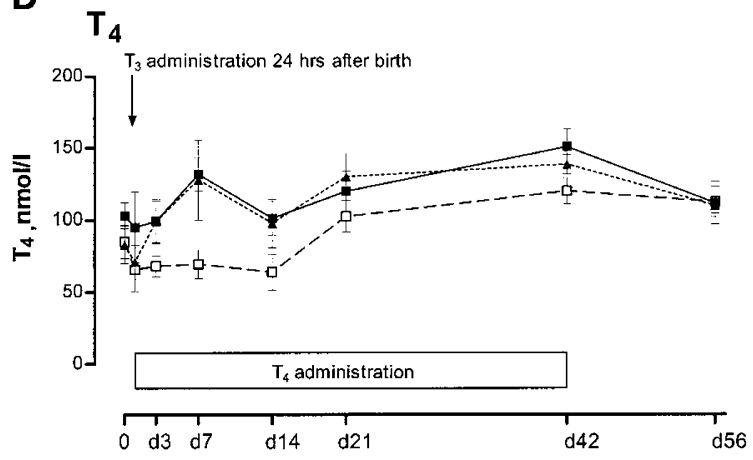

F

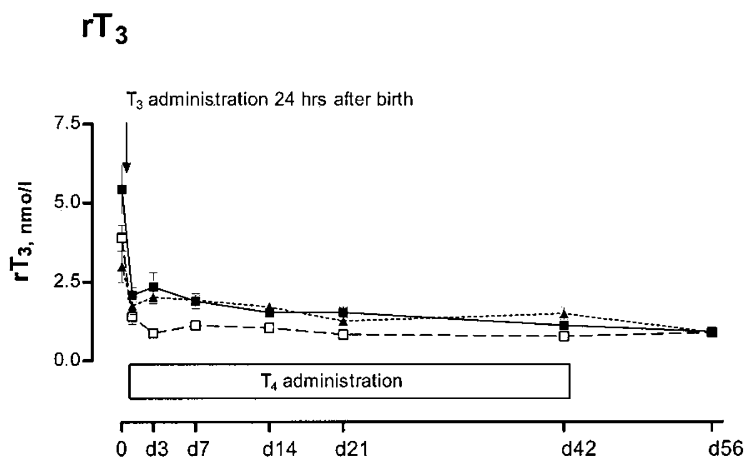

G

Cortisol

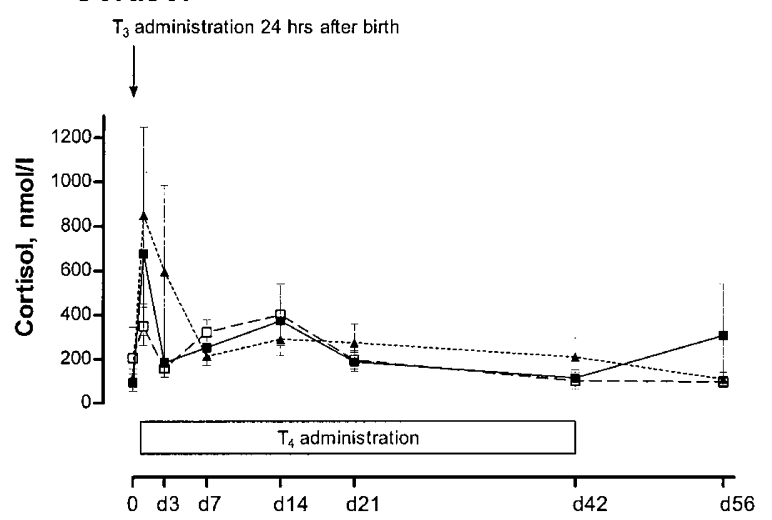

Figure 1. Hormonal outcome. Plasma concentrations of $\mathrm{T}_{3}(A), \mathrm{FT}_{3}(B), \mathrm{FT}_{4}(C), \mathrm{T}_{4}(D), \mathrm{TSH}(E), \mathrm{rT}_{3}(F)$, and cortisol $(G)$. Values presented are means \pm SEM. $\square$, group A; $\boldsymbol{\Lambda}$, group B; $\square$, group C. The $x$ axis represents time after birth. The $x$ axis of $A$ consists of three parts with different scales (birth to $24 \mathrm{~h}$ after birth, 30-360 min after $\mathrm{T}_{3}$ administration, and day 3 to day 56 after birth). The moment of $\mathrm{T}_{3}$ administration and the period of $\mathrm{T}_{4}$ administration are indicated. Statistical significance $(p<0.05)$ is indicated with * for significance compared with group $\mathrm{C}$ and with ${ }^{*}$ compared with group B. In $C$, the * on day 7 indicates statistical significance of group A compared with group C. 
Mean $\mathrm{rT}_{3}$ levels in all groups were highest in cord blood (group A, $5.4 \pm 0.8 \mathrm{nmol} / \mathrm{L}$; group B, $3.0 \pm 0.5 \mathrm{nmol} / \mathrm{L}$; group $\mathrm{C}, 3.9 \pm 0.4 \mathrm{nmol} / \mathrm{L}$ ). During the whole period of $\mathrm{T}_{4}$ administration, mean $\mathrm{rT}_{3}$ levels were higher in groups $\mathrm{A}$ and $\mathrm{B}$ compared with those in group $\mathrm{C}$, although significance was not reached at all points. $\mathrm{T}_{3}$ administration did not influence the time course of mean $\mathrm{rT}_{3}$ levels.

Mean cortisol levels showed a peak at $24 \mathrm{~h}$ after birth (before $\mathrm{T}_{3}$ and $\mathrm{T}_{4}$ administration was started) and a lower peak $14 \mathrm{~d}$ after birth in all groups and stayed comparable between the groups. $\mathrm{T}_{3}$ and $\mathrm{T}_{4}$ administration did not influence the time course of cortisol levels.

Cardiovascular outcome. The cumulative doses of inotropic agents in the three groups are shown in Table 2. Mean heart rates, mean arterial blood pressure, and cumulative dose of inotropic agents showed no statistically significant differences among the three study groups, although the cumulative dose of inotropic agents was somewhat higher in group A compared with groups $B$ and $C$. Even during the period of higher $T_{3}$ levels (days 1-3) in group A, there were no significant differences in mean heart rate, mean daily blood pressure, or daily use of inotropic agents.

\section{DISCUSSION}

In this randomized, placebo-controlled trial, we have studied the effect of $T_{3}$ plus $T_{4}$ administration in comparison with $T_{4}$ supplementation alone and with a placebo-treated control group on thyroid hormone and cortisol levels and on the cardiovascular condition in preterm infants. We found a significant, short-lasting increase in $T_{3}$ levels after the $T_{3}$ bolus without any effect of $\mathrm{T}_{3}$ administration on concentrations of $\mathrm{T}_{4}$, $\mathrm{FT}_{4}$, and $\mathrm{rT}_{3}$. TSH levels in the group that received combined $\mathrm{T}_{3}$ and $\mathrm{T}_{4}$ were less suppressed on day 42 than in the group that received $\mathrm{T}_{4}$ alone.

In an earlier study from our group (17), we described a longitudinal $T_{3}$ increase after a single $T_{3}$ dose, given $12 \mathrm{~h}$ after birth, in comparison with historical controls. We hypothesized that this $\mathrm{T}_{3}$ increase was caused by a $\mathrm{T}_{3}$-mediated induction of type 1 deiodinase expression (24), most probably of thyroidal origin, causing increased levels of $\mathrm{T}_{3}$ as a result of increased conversion of $T_{4}$ to $T_{3}$. In this study, our findings are less strong.

$\mathrm{T}_{3}$ is known to be decreased as a result of $\mathrm{T}_{4}$ administration (16). Indeed, also in this study, $\mathrm{T}_{3}$ concentrations were in the lowest range in the $T_{4}$ group. In the $T_{4}$ plus $T_{3}$ group, $T_{3}$ concentrations were somewhat higher on day 21 and day 42 compared with the $\mathrm{T}_{4}$ group, but not significantly.

TSH seemed to be less suppressed in the $T_{4}$ plus $T_{3}$ group, compared with the $\mathrm{T}_{4}$ group on day 42. A possible explanation for this higher TSH concentration could be the more severe illness in this group with a more pronounced rebound in TSH secretion when nonthyroid illness resolved.

In an earlier study, we found a clear nadir in the mean $\mathrm{FT}_{4}$ concentration at approximately day 7 in a placebo group of preterm infants (25). It was also found that disease decreased $\mathrm{FT}_{4}$ concentrations, especially during the first week of life. In a recent and larger study from the United Kingdom (26), an
$\mathrm{FT}_{4}$ nadir was also found in infants of comparable GAs. In the present study, we did not find this nadir in the mean $\mathrm{FT}_{4}$ concentrations in the placebo group, although our lowest $\mathrm{FT}_{4}$ concentrations between day 3 and day 14 were well comparable with those from our earlier study (25). Although we cannot readily explain the different course in time in the placebo group, it could be due to the somewhat better clinical condition in this small study group.

Cortisol levels in all three study groups showed a longitudinal pattern similar to that described by others in preterm infants $(27,28)$. Although glucocorticoid hormones and thyroid hormones are known to influence each other's regulation in animal studies (18), we could not demonstrate any effect of $\mathrm{T}_{3}$ and/or $\mathrm{T}_{4}$ supplementation on cortisol levels. This is an important observation, as hypocortisolism is often suspected in sick preterm infants, and the need for cortisol supplementation in these infants is under ongoing debate (29). As cortisol levels did not differ among the study groups at time points on which low thyroid hormone levels were measured in one or two study groups, our study suggests that hypothyroxinemia is not involved in the development of hypocortisolism. In a recent study published by Biswas et al. (26), no effect of simultaneous administration of $T_{3}$ and hydrocortisone on pulmonary outcome was found, whereas in agreement with our results, no relationship between free thyroid hormone concentrations and plasma cortisol levels was found within the study group.

Several studies have suggested that $\mathrm{T}_{3}$ and $\mathrm{T}_{4}$ administration influences the cardiovascular system (20-23). We did not find any effect of $\mathrm{T}_{3}$ or $\mathrm{T}_{4}$ administration on the cardiovascular parameters measured. A possible explanation for this negative finding is the worse clinical condition of the infants in the group that received $T_{3}$ plus $T_{4}$ requiring relatively more inotropic agents for low blood pressure. It could also be that only a regimen of daily $T_{3}$ administration results in measurable cardiovascular effects.

Indeed, that our group A had a lower mean birth weight and a less favorable clinical course is a limitation in the interpretation of the results of this study. In this group, there were more deaths (NS) and significantly more infants with grades 3 and 4 intracranial bleeding. We do not believe that there is a causal relationship between $\mathrm{T}_{3}$ plus $\mathrm{T}_{4}$ administration and the clinical course, because of the unchanged cardiovascular parameters and the far too low power of this study to pick up such an effect, but of course, we cannot rule it out either.

The lack of both positive clinical findings and pronounced changes in thyroid hormone levels, especially $\mathrm{T}_{3}$ levels, does not support the use of $T_{3}$ in preterm infants according to our regimen. For future studies in this field this could indicate that other treatment regimens, for example, with a daily or higher dose of $T_{3}$, might be more successful in improvement of both hormonal and clinical outcome.

Acknowledgments. We thank Bas Kulderij and Erik Endert from the Laboratory of Endocrinology of the Academic Medical Center, Amsterdam, for assistance with the processing of the blood samples and the endocrinological measurements used in this study. We also thank Debbie Nuytemans and Elly Jansen from the Department of Clinical Pharmacology of the 
Academic Medical Center, Amsterdam, for assistance in the preparation of the study medication.

\section{REFERENCES}

1. Bernal J, Nunez J 1995 Thyroid hormones and brain development. Eur J Endocrinol 133:390-398

2. Timiras PS, Nzekwe EU 1989 Thyroid hormones and nervous system development. Biol Neonate 55:376-385

3. Adams LM, Emery JR, Clark SJ, Carlton EI, Nelson JC 1995 Reference ranges for newer thyroid function tests in premature infants. J Pediatr 126:122-127

4. Cuestas RA 1978 Thyroid function in healthy premature infants. J Pediatr 92:963-967

5. Hadeed AJ, Asay LD, Klein AH, Fisher DA 1981 Significance of transient postnatal hypothyroxinemia in premature infants with and without respiratory distress syndrome. Pediatrics 68:494-498

6. Harkavy KL, Enecio CE 1991 Free thyroxine levels in hospitalized newborns: depressed levels in critical, nonthyroidal illness. J Perinatol 11:117-121

7. Uhrmann S, Marks KH, Maisels MJ, Kulin HE, Kaplan M, Utiger R 1981 Frequency of transient hypothyroxinaemia in low birthweight infants. Potential pitfall for neonatal screening programmes. Arch Dis Child 56:214-217

8. Den Ouden AL, Kok JH, Verkerk PH, Brand R, Verloove-Vanhorick SP 1996 The relation between neonatal thyroxine levels and neurodevelopmental outcome at age 5 and 9 years in a national cohort of very preterm and/or very low birth weight infants. Pediatr Res 39:142-145

9. Lucas A, Morley R, Fewtrell MS 1996 Low triiodothyronine concentration in preterm infants and subsequent intelligence quotient (IQ) at 8 year follow up. BMJ 312:11321134

10. Reuss ML, Paneth N, Pinto-Martin JA, Lorenz JM, Susser M 1996 The relation of transient hypothyroxinemia in preterm infants to neurologic development at two years of age. N Engl J Med 334:821-827

11. van Wassenaer AG, Briet JM, van Baar A, Smit BJ, Tamminga P, De Vijlder JJM, Kok JH 2002 Free thyroxine levels during the first weeks of life and neurodevelopmental outcome until the age of 5 years in very preterm infants. Pediatrics 110:534539

12. Chowdhry P, Scanlon JW, Auerbach R, Abbassi V 1984 Results of controlled double-blind study of thyroid replacement in very low-birth-weight premature infants with hypothyroxinemia. Pediatrics 73:301-305

13. van Wassenaer AG, Kok JH, de Vijlder JJ, Briet JM, Smit BJ, Tamminga P, van Baar A, Dekker FW, Vulsma T 1997 Effects of thyroxine supplementation on neurologic development in infants born at less than 30 weeks' gestation. N Engl J Med $336: 21-26$

14. Vanhole C, Aerssens P, Naulaers G, Casneuf A, Devlieger H, Van den BG, de Zegher F 1997 L-thyroxine treatment of preterm newborns: clinical and endocrine effects. Pediatr Res 42:87-92
15. Briet JM, van Wassenaer AG, Dekker FW, de Vijlder JJ, van Baar A, Kok JH 2001 Neonatal thyroxine supplementation in very preterm children: developmental outcome evaluated at early school age. Pediatrics 107:712-718

16. van Wassenaer AG, Kok JH, Dekker FW, Endert E, de Vijlder JJ 1998 Thyroxine administration to infants of less than 30 weeks gestational age decreases plasma tri-iodothyronine concentrations. Eur J Endocrinol 139:508-515

17. Cools F, van Wassenaer AG, Kok JH, de Vijlder JJ 2000 Changes in plasma thyroid hormone levels after a single dose of triiodothyronine in premature infants of less than 30 weeks gestational age. Eur J Endocrinol 143:733-740

18. Darras VM, Kotanen SP, Geris KL, Berghman LR, Kuhn ER 1996 Plasma thyroid hormone levels and iodothyronine deiodinase activity following an acute glucocorticoid challenge in embryonic compared with posthatch chickens. Gen Comp Endocrinol 104:203-212

19. Tohei A, Watanabe G, Taya K 1998 Hypersecretion of corticotrophin-releasing hormone and arginine vasopressin in hypothyroid male rats as estimated with push-pull perfusion. J Endocrinol 156:395-400

20. Bettendorf M, Schmidt KG, Grulich-Henn J, Ulmer HE, Heinrich UE 2000 Triiodothyronine treatment in children after cardiac surgery: a double-blind, randomised, placebo-controlled study. Lancet 356:529-534

21. Broderick TJ, Wechsler AS 1997 Triiodothyronine in cardiac surgery. Thyroid 7:133-137

22. Portman MA, Fearneyhough C, Ning X-H, Duncan BW, Rosenthal GL, Lupinetti FM 2000 Triiodothyronine repletion in infants during cardiopulmonary bypass for congenital heart disease. J Thorac Cardiovasc Surg 120:604-608

23. van Wassenaer AG, Kok JH, Briet JM, Pijning AM, de Vijlder JJ 1999 Thyroid function in very preterm newborns: possible implications. Thyroid 9:85-91

24. Maia AL, Kieffer JD, Harney JW, Larsen PR 1995 Effect of 3,5,3'-Triiodothyronine (T3) administration on diol gene expression and T3 metabolism in normal and type 1 deiodinase-deficient mice. Endocrinology 136:4842-4849

25. van Wassenaer AG, Kok JH, Dekker FW, De Vijlder JJM 1997 Thyroid function in very preterm infants: influences of gestational age and disease. Pediatr Res 42:604609

26. Biswas S, Buffery J, Enoch H, Bland M, Markiewicz M, Walters D 2003 Pulmonary effects of triiodothyronine (T3) and hydrocortisone (HC) supplementation in preterm infants less than 30 weeks gestation: results of the THORN trial-thyroid hormone replacement in neonates. Pediatr Res 53:48-56

27. Midgley PC, Holownia P, Smith J, Moore M, Russell K, Oates N, Shaw JCL, Honour JW 2001 Plasma cortisol, cortisone and urinary glucocorticoid metabolites in preterm infants. Biol Neonate 79:79-86

28. Scott SM, Watterberg KL 1995 Effect of gestational age, postnatal age, and illness on plasma cortisol concentrations in premature infants. Pediatr Res 37:112-116

29. Watterberg KL, Gerdes JS, Cook KL 2001 Impaired glucocorticoid synthesis in premature infants developing chronic lung disease. Pediatr Res 50:190-195 